\title{
Effects of Cathodic Currents on the Corrosion of an Aluminum Alloy
}

\author{
William J. Schwerdtfeger
}

(May 28, 1964)

\begin{abstract}
A laboratory investigation was made using 6063-T5 aluminum alloy. In order to determine the most anodic potentials of the alloy under varying conditions of $p \mathrm{H}$ specimens were exposed for 6 months to 21 water-saturated soils (air free) ranging in $p \mathrm{H}$ from 3.4 to 10.0. The data obtained should be useful in selecting protective potentials where cathodic protection is desirable and feasible.

The effects of continuously applied cathodic currents were studied by exposing the alloy for 6 months to still city water to which was added 3 percent by weight of sodium chloride. In addition, the effect of $p H$ was observed by using similar salt water solutions, adjusted to $p \mathrm{H} 4$ and $p \mathrm{H}$ 10. In each environment, cathodic and anodic polarization data were obtained periodically on freely corroding specimens. The cathodic data were used to choose protective potentials and together with the anodic data to calculate instantaneous rates of corrosion. The data indicate that cathodic protection is feasible, especially in the low- $p \mathrm{H}$ range. Cathodic corrosion occurred at $p \mathrm{H} 10$ and can occur even at a lower $p \mathrm{H}$.
\end{abstract}

\section{Introduction}

Aluminum and its alloys have an enviable reputation for resistance to atmospheric corrosion. Their ability to resist corrosion is attributed to the rapid formation of protective oxide films. However, the behavior of aluminum to underground and aqueous exposures is somewhat controversial. A breakdown of the oxide film will result in varying degrees of corrosion depending on such factors as differential aeration, $p \mathrm{H}$, and conductivity of the electrolyte.

Aluminum alloys are subject to corrosion in some aqueous and underground environments hence it seems logical to think in terms of protection such as applied to ferrous structures. Iron and steel are protected by coatings, cathodic protection, or a combination of both. However, upon searching the literature one soon learns that the application of cathodic protection to aluminum is fraught with many uncertainties. There is the possibility of cathodic corrosion, a factor which is no cause for concern in the cathodic protection of iron and steel. Also, even a break in or loosening of a coating on aluminum exposed to a very corrosive environment can result in accelerated attack because of a breakdown of the oxide film.

Mears and Brown [1] ${ }^{1}$ have suggested that aluminum can be cathodically protected provided that

\footnotetext{
1 Figures in brackets indicate the literature references at the end of this paper.
}

the current density is below a critical value. Caldwell and Albano [2] found that in a neutral salt solution, when aluminum is cathodic, the increase in hydroxyl-ion concentration will corrode the metal if the current density is excessive. These investigators also said that in a strongly alkaline solution $(\mathrm{NaOH}$ $0.1 N$ to $0.25 N$ ) the increase in hydroxyl-ion at the cathode is negligible compared with the concentration of alkali in the body of the electrolyte, hence cathodic protection will have no effect. In a discussion of this paper, Mears and Brown [3] again stated that cathodic protection is possible in neutral chlorides or near neutral solutions provided current densities are not too high. Still later, Mears [4] pointed out that cathodic corrosion is caused by excessive current and that to his knowledge there was no case on record where aluminum has been cathodically corroded when zinc was the sacrificial anode, but corrosion has been known to occur where magnesium or external current was used. He also mentioned that while zine is anodic to aluminum in acid solutions it is also severely attacked and is therefore undesirable. Because of the amphoteric nature of aluminum, Mears mentioned that the use of cathodic protection may not be feasible in alkaline solutions because of the increased concentration of alkali on the cathode caused by the current.

Wanderer and Sprowls [5] concluded that cathodic protection was unnecessary in referring to aluminum pipe alloys 6063-T5 and 6061-T6 exposed to saline water. 
Dalrymple [6] reported virtually no corrosion, after 5 years of exposure on $8 \frac{3}{4}$ in. o.d. aluminum alloy (6063) pipeline buried unprotected in $10,000 \mathrm{ohm}-\mathrm{cm}$ soil. Nevertheless, he suggested coating aluminum lines and supplementing this with cathodic protection to eliminate the hazards of corrosion in soils.

Deltombe and Pourbaix [7] reported that cathodic protection of aluminum is practically impossible because of the low value of the protective potential $\left(-1.78 \mathrm{~V}, \mathrm{H}_{2}\right.$ scale $)$.

Sprowls and Carlisle [8] concluded that it is difficult to predict the performance of aluminum underground from characteristics of the soil and that some soils cause severe corrosion on aluminum and aluminum alloys. They subscribe to the feasibility of cathodic protection, as demonstrated in some environments, indicating that eventually cathodic protection may permit bare aluminum alloys to be buried in the most corrosive soils. In cathodically protecting aluminum pipe (6063-T5) for 8 years in $3500 \mathrm{ohm}-\mathrm{cm}$ soil $(p \mathrm{H}$ 6.1) they found the deepest pit to be only 22 mils as compared with 80 mils on unprotected pipe. The potentials of the protected pipe varied between -0.9 and $-1.1 \mathrm{~V}$ referred to the coppercopper sulfate electrode. Sprowls and Carlisle tentatively suggested a protective potential between -0.9 and $-1.2 \mathrm{~V}$ referred to copper-copper sulfate and warn that excessive current densities can cause cathodic corrosion.

Whiting and Wright [9] tell of deep pitting on an unprotected aluminum (AA3003) pipeline 11 months after installation in areas where the soil resistivity was less than 1500 ohm-cm. Magnesium anodes were then installed which resulted in an average current density of $0.225 \mathrm{~mA} / \mathrm{ft}^{2}$ and a pipe potential of $-1.0 \mathrm{~V}$ or more to a copper-copper sulfate electrode. After an additional 9 months, the line was reexcavated for inspection and an examination revealed that corrosion had been arrested.

In cathodic protection tests made with aluminum alloy specimens buried in 400 to $1000 \mathrm{ohm}-\mathrm{cm}$ soil, Hewes [10] found no severe cathodic corrosion on specimens maintained at potentials as high as -1.5 $V$ with reference to the copper-copper electrode and therefore believes that the potential of $-1.2 \mathrm{~V}$ as an upper limit is too conservative.

In view of the foregoing, it appears that additional research is warranted in order to learn more about the effects of cathodic current on aluminum. The alloy $6063-\mathrm{T} 5{ }^{2}$ was chosen for this investigation. An experiment was designed to measure the maximum anodic potential of the alloy specimens in various soils ranging in $p \mathrm{H}$ from 3.4 to 10.0 and to select a value as the protective potential. All of the other experiments involving applied current were carried out with a 3 percent sodium chloride solution and also with a similar solution made both acidic and alkaline by the addition of acetic acid and sodium carbonate, respectively.

\footnotetext{
${ }^{2}$ Nominal composition, in percent: $0.7 \mathrm{Mg}, 0.4 \mathrm{Si}, \mathrm{Al}$ and normal impurities
} constitute the remainder.

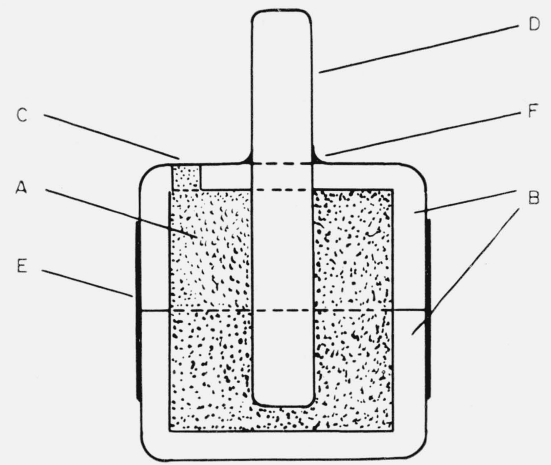

Figure 1. Cell for measuring the potential of an aluminum alloy in a soil.

A, soil; B, rubber caps; C, hole for contact between soil and reference electrode; D, alloy; E, tape; F, sealer.

\section{Experimental Procedure}

\subsection{Preparation and Exposure of Specimens for Potential Measurements in Soils}

Specimens were cut to a length of $3 \frac{1}{4}$ in. from $1 / 2$ in. diam aluminum alloy rods. Two were prepared for each of 21 soils. The soils varied in $p \mathrm{H}$ from 3.4 to 10.0 , the majority of them being classified as poorly aerated with resistivities less than 500 ohm-cm. Chemical and physical properties of the soils, with the exception of 3 soils $(126,127,128)$ from new test sites, have been published [11]. Soils at sites 126,127 , and 128 have resistivities under 500 ohm-cm. Numbers 126 and 127 are poorly aerated and No. 128 is well aerated. A crosssectional sketch of the cell used for measuring potentials is shown in figure 1. Finely ground soil, A, saturated with distilled water and puddled was carefully packed into two rubber caps, B. Before packing, two holes were drilled in the upper cap, one $1 / 4$ in. diam, C, for permitting contact between the soil and the reference electrode and the other $1 / 2$ in. diam to accommodate the alloy specimen, D. The cell shown in figure 1 is drawn to scale, each cap being 1 in. deep and $17 \frac{7 / 8}{\text { in. i.d. The alloy was }}$ cleaned in varsol, the edges rounded off, the entire surface rubbed vigorously with fine grit abrasive cloth, scrubbed under hot running water with soap and rinsed. After packing soil around the specimen positioned in the upper cap and then packing the other cap, the cell was assembled as shown, care being taken to leave no voids in the soil. The caps were then joined and sealed with polyvinyl-chloride pressure-sensitive tape, E. A mixture of paraffin and beeswax, F, was used for sealing between the specimen and the cap. To prevent the soil in the cells from drying out, the hole $\mathrm{C}$ was covered with a patch of polyvinyl tape and then the cells were stored in a water-saturated enclosure. The cells were removed from this environment for about 25 min per week in order to make potential measure- 
ments. One cell of each pair was disassembled after 6 months. The remaining 21 cells were left assembled for an additional 18 weeks for reasons to be discussed later.

\subsection{Preparation and Exposure of Specimens With Applied Cathodic Currents}

Eight pairs of specimens were prepared, each pair from a single $1 / 2$ in. diam aluminum alloy rod and each specimen cut to a length of 18 in. 'They were cleaned for exposure as previously described for the soil specimens and weighed to the nearest $2 \mathrm{mg}$. Finally, except for 9 in. on one end (approximately $0.1 \mathrm{ft}^{2}$ ) for exposure to the electrolyte and $1 \mathrm{in}$. on the other end for an electrical connection, each specimen was spirally wrapped with polyvinylchloride pressure-sensitive tape.

Three pairs of specimens, each pair consisting of a freely corroding specimen (control) and a cathode, were exposed for approximately 6 months to Washington, D.C., city water to which had been added 3 percent by weight of sodium chloride. The salt water was contained in a wooden vat about 66 in. i.d. and maintained at a depth of 18 in.; the volume of water being about 265 gal. The water temperature was not controlled but was measured regularly during the exposure period. A photograph of some of the specimens, just prior to removal, during exposure to the salt water is shown in figure 2 . Three zinc rods, one for each cathode, were used as auxiliary electrodes. The specimens were left undisturbed throughout the entire exposure period, wires from the specimens being connected to a terminal block mounted on the side of the vat.

The remaining 5 pairs of specimens were set up in 5 Pyrex jars (approximately 12 in. in diameter by 12 in. high) containing about 4.5 gal of city water with 3 percent by weight of sodium chloride added. The salt water in 2 of these jars was made alkaline by the addition of sodium carbonate while the water in 2 other jars was make acidic by the addition of acetic acid. The $p \mathrm{H}$ of the alkaline solutions was maintained between 9.7 and 10.0 and that of the acid solutions was kept between 4.0 and 4.3. One of the jars was left with the salt water only shown in the foreground of the photograph, figure 3. Each jar contained 2 specimens, one corroding freely and the other made cathodic. It will be seen in the photograph that the specimens in the front jar are fitted with cylindrical objects about centrally located on the rods. These are rubber caps (open end up), similar to those used for the soil cells previously described, filled with clay soil in order to concentrate the corrosion in that area. With the exception of the two jars in the background containing acidic salt solutions, zinc strips were used as auxiliary anodes located diametrically opposite each other; the center specimen was the cathode. An aluminum alloy was used as the auxiliary anode in the acidic salt solutions as zinc corroded very rapidly. The

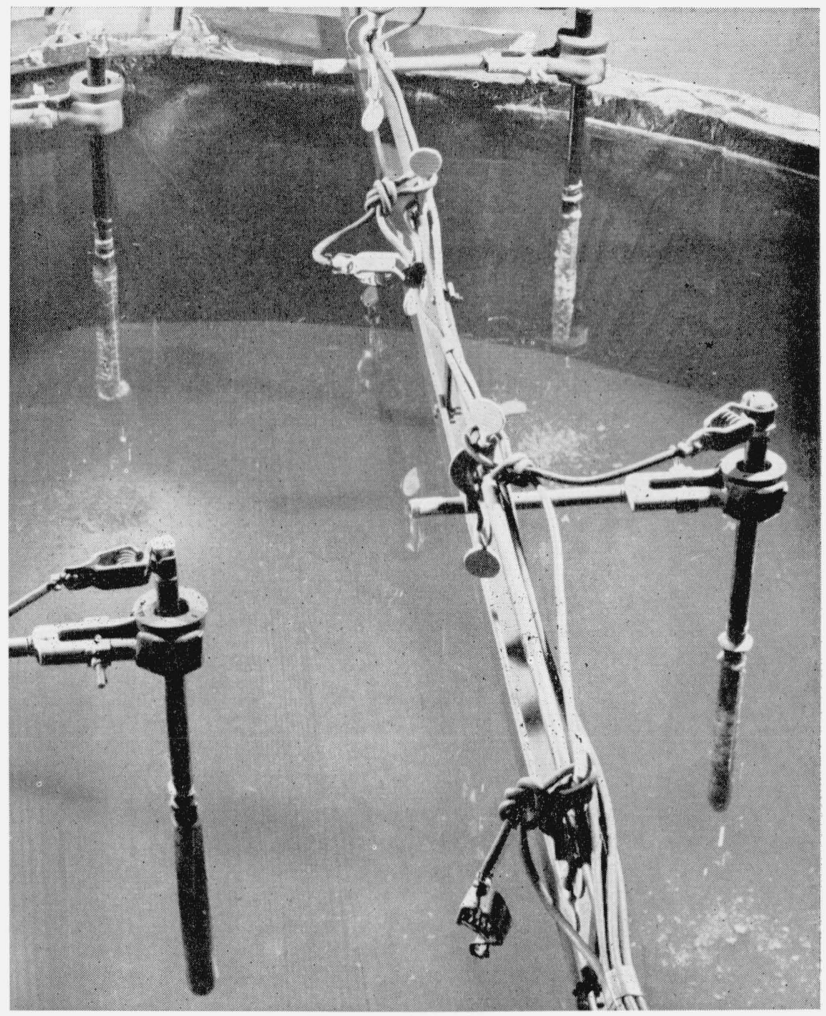

FiguRE 2. Aluminum alloy specimens exposed to salt solution in wooden vat. Specimens 9 and 10, foreground, right and left, respectively.
Specimens 7 and 8, background, right and left, respectively. Note absence of corrosion products on floor of vat under cathode 10 (protected).

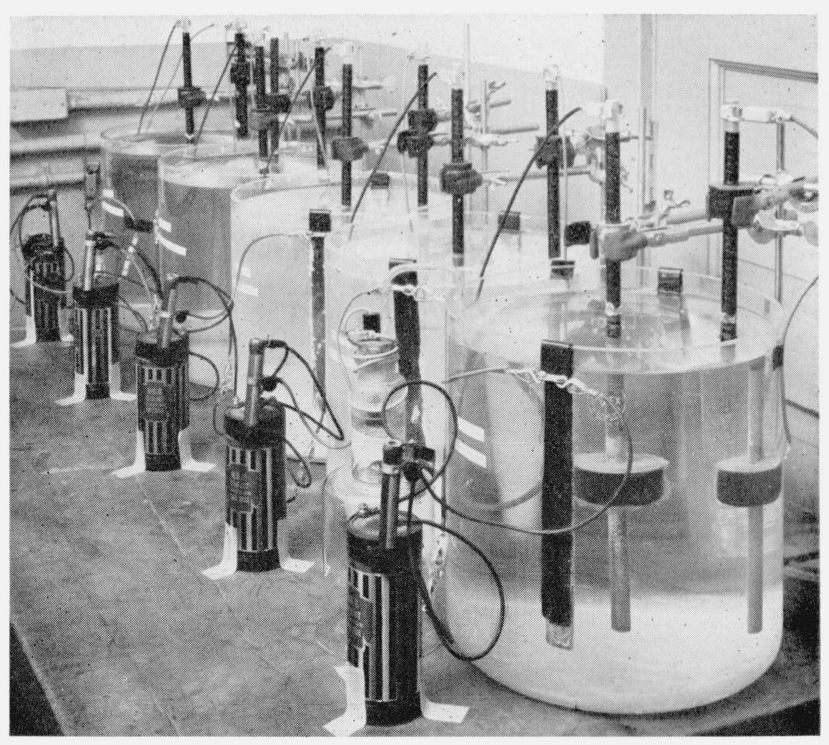

Figure 3. Aluminum alloy specimens exposed to solutions in the jars.

temperatures of the electrolytes were measured periodically although no attempt was made to regulate them. The specimens in the jars were also exposed for about 6 months. 


\section{a. Electrical Measurements}

Potentials of the alloy in the 21 soils were measured about weekly with a potentiometer and a saturated calomel half-cell. ${ }^{3}$ When making potential measurements, direct contact between the soil and the calomel half-cell was avoided by using an intermediate electrolyte of puddled soil. This procedure prevented contamination of the soil in the cell by salt from the agar-salt bridge. At the end of 6 months, when one cell of each soil was taken apart, the $p \mathrm{H}$ of the 21 soils adjacent to the specimens was measured. For most soils, the $p \mathrm{H}$ was not sionificantly different from the value measured before the cells were assembled. The temperature of the room where the cells were stored varied between 70 and $90^{\circ} \mathrm{F}$. This variation in temperature would account for less than a $10 \mathrm{mV}$ change in the potential of the saturated calomel half-cell [12].

For the cathodes in the salt solutions, except for one in the wooden vat which was connected directly to a zinc anode, a $500 \mathrm{ohm}$ voltage-divider connected across a $1.5 \mathrm{~V}$ No. 6 dry cell was used to control potential and furnish applied current. This arrangement made it possible to hold the potential of a cathode within $\pm 15 \mathrm{mV}$, usually closer.

Potentials and applied currents were measured about twice weekly. The potentials, referred to the saturated calomel electrode, were measured with a potentiometer and then the currents with a milliammeter. The currents were checked occasionally with a zero-resistance milliammeter. The potentials of some of the cathodes were adjusted on the basis of data obtained from cathodic polarization curves on the controls. IR drops associated with potential measurements were negligible. Polarization data were obtained weekly or biweekly. Anodic polarization data were also obtained, usually the day after making the cathodic measurements. A two-pen strip-chart recorder was used for these measurements. The polarizing current resulted from linear increments in applied voltage obtained with a synchronously driven 10-turn potentiometer connected across a battery which delivered current through two zinc lectrodes exposed to the solutions only while olarization measurements were being made.

\section{b. Removal of Corrosion Products}

All specimens were removed from the solutions after about 6 months of exposure. Loose corrosion products were removed with a nonmetallic bristle brush while the specimens were held under running hot water. Following this, they were immersed for $10 \mathrm{~min}$ in an aqueous solution consisting of 5 percent phosphoric acid and 2 percent chromic acid at $90{ }^{\circ} \mathrm{C}$ contained in an ultrasonic cleaning tank. After rinsing with running hot water and drying by blowing compressed air over the surface, the specimens were weighed. The cycle was repeated until there was no significant weight change, but usually the first cleaning was found to be sufficient.

${ }^{3}$ All potentials specified hereafter are with respect to the saturated calomel half-cell.

\section{Results and Discussion}

\subsection{Potentials of the Aluminum Alloy in Air-Free Soils}

A logical step in experimentally determining a protective potential generally applicable to a partic. ular aluminum alloy in soils, assuming that cathodic protection is possible, would be that of measuring the most anodic potentials of the alloy peculiar to a variety of soils covering the $p \mathrm{H}$ range. These potentials would presumably exist under oxygen-deficient conditions or during exposure in so-called air-free soils. Cells were assembled as previously described with this idea in mind.

Potentials based on two specimens for each of the 21 soils (fig. 4) are plotted versus the $p H$ of the soil, the $p \mathrm{H}$ measured being the value upon disassembly. The potentials were measured between the $2 \mathrm{~d}$ and 6 th months of exposure when day-by-day variations in potential were less than during the first 2 months. Maximum, minimum and average potentials are shown. Where the range of potentials for a given soil during the 4 month period is not over $100 \mathrm{mV}$, the potentials of a pair of specimens were always within $20 \mathrm{mV}$. Where the difference between maximum and minimum is over $100 \mathrm{mV}$, the greater part of the potential difference can be attributed to aeration differences between cells of a pair.

There appears to be no consistent relationship between $p H$ and potential. The specimen in the most alkaline soil, 116 , does have the most anodic potential. The specimen in soil $13(p \mathrm{H} 8.9)$ has the most cathodic potential $(-0.68 \mathrm{~V})$ but during early exposure was $-1.28 \mathrm{~V}$.

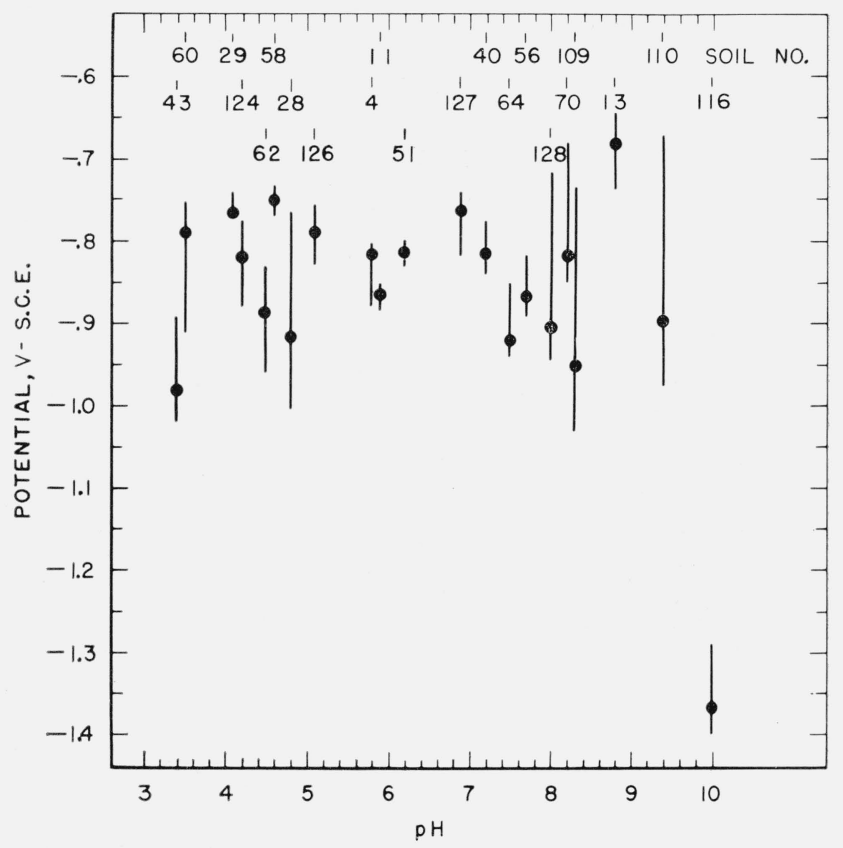

Figure 4. Relation between the potential of aluminum alloy (6063-T5) in air-free soil and the $p \mathrm{H}$ of the soil.

Range of potentials and average potential of 2 specimens in 21 soils from $2 \mathrm{nd}$ through 6th month of exposure. 
Limited, yet significant, data were also obtained on the 21 soil cells which were kept in operation for an additional 18 weeks. The cells were left stored in the water-saturated environment as during the previous 6 months except that 1 in. of tape was cut from that which held the two rubber caps of the cell together so as to permit access of air to the soil. The effect, without exception, was to make the potentials more cathodic, that is more typical of the normal corrosion potentials. Except for soil 116 $(p \mathrm{H} \mathrm{10)}$ in which the potential was $-1.06 \mathrm{~V}$ at the end of 18 weeks, the range of potentials varied between $-0.64 \mathrm{~V}$ (soils 58,124 ) and $-0.895 \mathrm{~V}$ (soil 64). This proves the effect of the exclusion of air in producing the more anodic potentials observed in the sealed cells.

There was a significant difference in corrosion rates of the specimens removed from the air-free soils from the rates in the same soils after permitting access of air for an additional 18 weeks. During the 6 months under air-free exposure the corrosion in all the soils was only superifial in nature being apparently the worst in soil 116. Strangely enough the specimen in soil 116 appeared about the same after 18 weeks more of aerated exposure but the specimens in soils 60,109 , and 127 had pits of 50,70 , and 110 mils deep, respectively. Pitting increased on the alloy in all the other soils (pits 20 to 40 mils on some) with the exception of soils 4 and 11 having resistivities of 6670 and 11,000 ohm-cm, respectively.

On the basis of the data (fig. 4) it appears that, with the exception of the extremely alkaline soil 116 , $-1.0 \mathrm{~V}$ (S.C.E.) might be a reasonable protective potential. However, experience at the site of one of the most corrosive soils (No. 127) shows otherwise. The site is a tidal marsh $(p \mathrm{H} 7)$ with a soil resistivity of about $300 \mathrm{ohm}-\mathrm{cm}$. Two aluminum alloy (3003) pipe specimens were buried there and connected directly to individual zinc anodes for an uninterrupted period of 30 months. The potentials of the couples just prior to removing them from the soil were about $-0.98 \mathrm{~V}$. Immediately after opencircuiting the couples, the potentials of the specimens were $-0.90 \mathrm{~V}$ and $-0.98 \mathrm{~V}$ and the current densities just before opening the circuits were $12 \mathrm{~mA} / \mathrm{ft}^{2}$ and $17 \mathrm{~mA} / \mathrm{ft}^{2}$, respectively. Severe cathodic corrosion took place on both specimens being worst on the one which had the higher current density. The potentials of the specimens remained almost unchanged for several minutes after the initial open-circuit readings; this aspect will be discussed later on experiments in the salt solutions. Another aluminum alloy (1188) specimen was buried at the same site and for about the same length of time. There is no reason to believe that there is any marked difference in the corrosion characteristics of the alloys mentioned in this paper. Cathodic polarization curves, such as those to be discussed later in connection with specimens in salt solutions, were obtained on the 1188 specimen after 8 and 30 months of uninterrupted burial. Based on the curves, the current presumably required for protection both times was between 5 and $6 \mathrm{~mA} / \mathrm{ft}^{2}$ and the corrosion potential was -0.65
V. These data suggest that the current densities on the 3003 specimens previously discussed were unnecessarily high and not self-regulating as probably would have been the case with steel cathodes. The curves on the aluminum cathodes indicated that complete protection was possible at about $-0.73 \mathrm{~V}$. The laboratory data for the 6063 alloy in the same soil suggest a value of $-0.765 \mathrm{~V}$ (fig. 4).

The wide range of potentials (fig. 4 ) and the field experience at site 127 leads the writer to conclude that a protective potential value, generally applicable to aluminum alloys in all soils, cannot be specified, even excluding strongly alkaline soils such as 116 . It is believed that changing the potential about $100 \mathrm{mV}$ by cathodic polarization is a safer approach in cathodically protecting aluminum alloys underground.

\subsection{Aluminum Alloy in Salt Solution}

Pertinent data pertaining to the effects of cathodic currents on the aluminum alloy exposed to salt water are given in table 1 . Specimens Nos. 7 through 12 were exposed to the salt water in the wooden vat. Specimens 7,9 , and 11 were permitted to corrode freely for 182 days, except at those times when polarization data were obtained which required a gradually increasing current for about $20 \mathrm{~min}$ per run. Specimens 8,10 , and 12 had cathodic currents applied continuously for 180 days after corroding freely for 2 days. High-purity zinc rods ( $3 / 8$ in. diam) were used as anodes, one for each of the cathodes. Some of the polarization data from the recorder charts replotted on semilogarithmic coordinates for control 9 are shown in figure 5. Curves such as these were used to determine the potential criterion $E_{a}$ (corresponding to the various values of $I_{p}$ ) and to calculate rates of corrosion [13].

Potentials and applied currents plotted versus time are shown in figure 6 for cathodes 8,10 , and 12 . Also shown are the corrosion potentials for control 7 (potentials for controls 9 and 11 corresponded within a few millivolts and are therefore omitted) and the currents, $I_{p}$, required for cathodic protection based on the controls. It will be noted for cathode 10 that the applied current corresponds reasonably well with the values of $I_{p}$.

A comparison of the cathodic effects based on three potential criteria, namely, $E_{a}$ (curves), $-1.0 \mathrm{~V}$ and $-1.5 \mathrm{~V}$ is given by the weight loss and remarks columns (table 1). The $-1.5 \mathrm{~V}$ (cathode 8) caused cathodic corrosion presumably because of the excessive current required to maintain the potential. Cathodes 10 and 12 were both protected to a reasonable degree but not as well as was hoped for. The potential on cathode 12 (connected directly to zinc anode) seemed to be more effective in reducing pitting (under the edge of the tape) than was potential $E_{a}$ applied to cathode 10 . This suggests, perhaps, that the potential corresponding to the beginning of the hydrogen over-voltage curve (at arrows, fig. 5) is more reasonable and also that $-1.0 \mathrm{~V}$ is not unreasonable. 
TABLE 1. Effect of cathodic currents on aluminum alloy (6063-T5) exposed for 6 months to salt solution ( $p H$ 8)

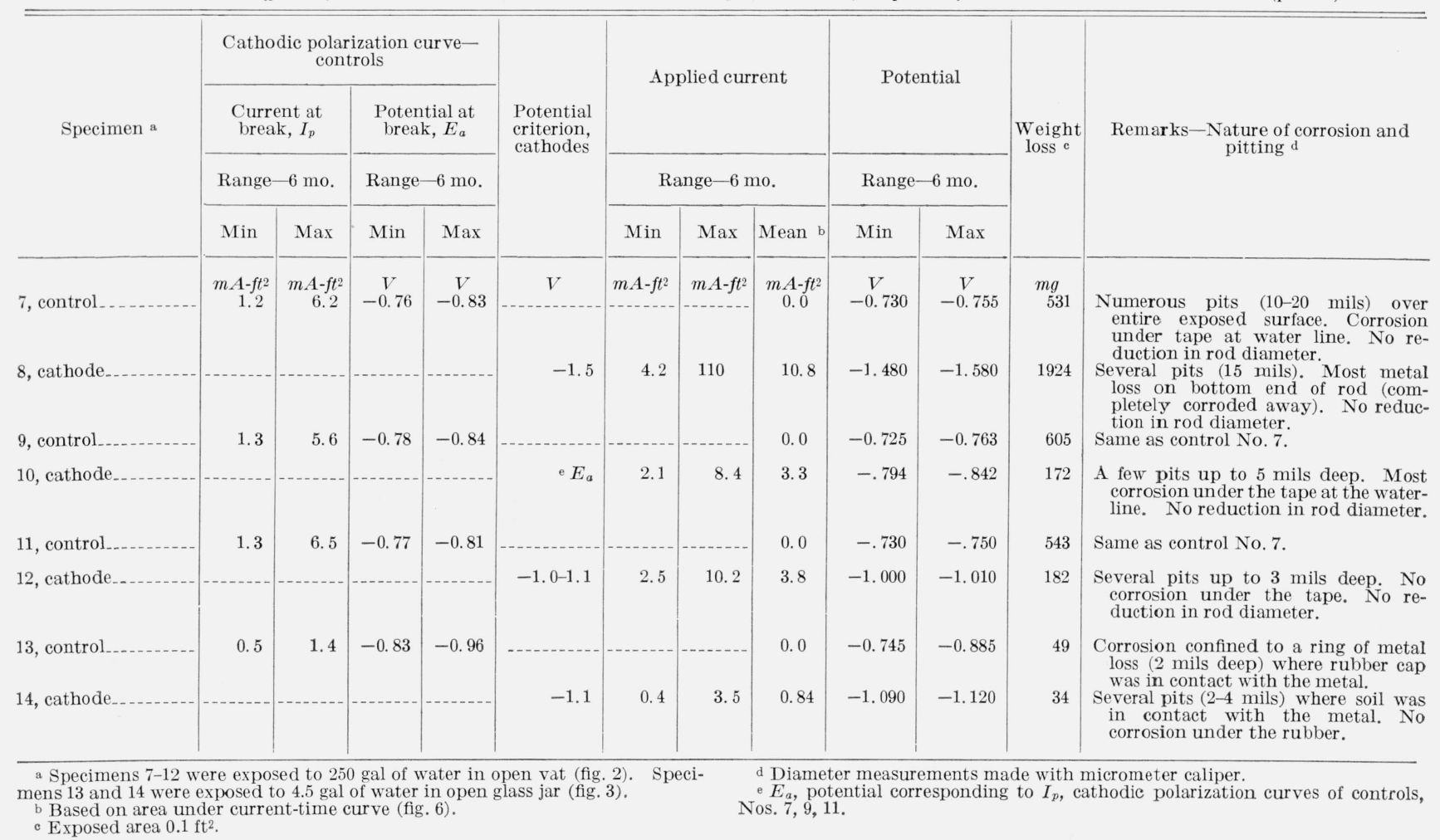

Based on the evidence in table 1 and that which is to follow for the salt solutions made alkaline and acidic, potential-decay curves obtained on the cathodes upon removing the applied currents appear to offer a clue as to whether cathodic protection had taken place or whether the currents caused cathodic corrosion. The curves (fig. 7) were recorded on cathodes 8, 10, and 12 after 180 days of exposure during which currents were applied continuously. Cathodic protection which took place on cathodes 10 and 12 is indicated by relatively rapid depolarization to the corrosion potentials of the controls while cathodic corrosion on cathode 8 seems to be indicated by little depolarization, with the potential remaining quite anodic to the corrosion potential of the control for a much longer period of time. Where cathodic protection has resulted, the better degree of protection appears to be associated with the greater depolarization. Depolarization to potentials which are cathodic to the corrosion potentials, as with cathodes 10 and 12 , might be explained by the increased cathodic area resulting from previous cathodic protection, the effect being only temporary while the applied current is off. The slow depolarization apparently associated with cathodic corrosion was also observed on the aluminum alloy 3003 exposed underground as previously described.

The pair of specimens 13 and 14 were exposed to salt water in the Pyrex jar. Data for this pair are shown in table 1 and in figures 8 and 9 . The corrosion rates on these specimens were less than 10 percent of those on the specimens exposed to the salt water in the large open vat. This is attributed in part to the lesser availability of oxygen in the jar. The clay soil contained in the rubber cap centrally positioned on each of the specimens was intended to localize the corrosion in that area. This turned out to be so, but the comparative weight losses of control 13 and cathode 14 do not indicate much benefit as a result of cathodic protection. However, visual examination of cathode 14 revealed the absence of a ring of corroded metal adjacent to the rubber so very evident on control 13 . The cathodic polarization data (fig. 8) indicated potentials (corresponding to the currents $I_{p}$ ) of between -0.8 and $-0.95 \mathrm{~V}$. Because it was anticipated that the metal in the soil area would be the most anodic, it was decided to hold the potential of cathode 14 at $-1.1 \mathrm{~V}$. Figure 9 indicates that, except for the first 25 days, this potential resulted in applied current density on cathode 14 which agreed quite well with what was required based on $I_{p}$. It may be of interest to mention that the $p \mathrm{H}$ of the soil adjacent to specimen 14, after 180 days, was 9.1 while the $p \mathrm{H}$ of the salt water was never over 8 . On the basis of figure 4 and figure 8 , it now appears as if a protective potential of about $-0.95 \mathrm{~V}$ would have been adequate and possibly given better protection. The potentialdecay curve (not shown) of cathode 14 revealed that after $15 \mathrm{~min}$ without applied current the potential was still about $0.1 \mathrm{~V}$ anodic to the potential of control 13. On the basis of what has been previously said about potential-decay curves, this suggests that there may have been some cathodic corrosion in the soil area where pitting took place. 


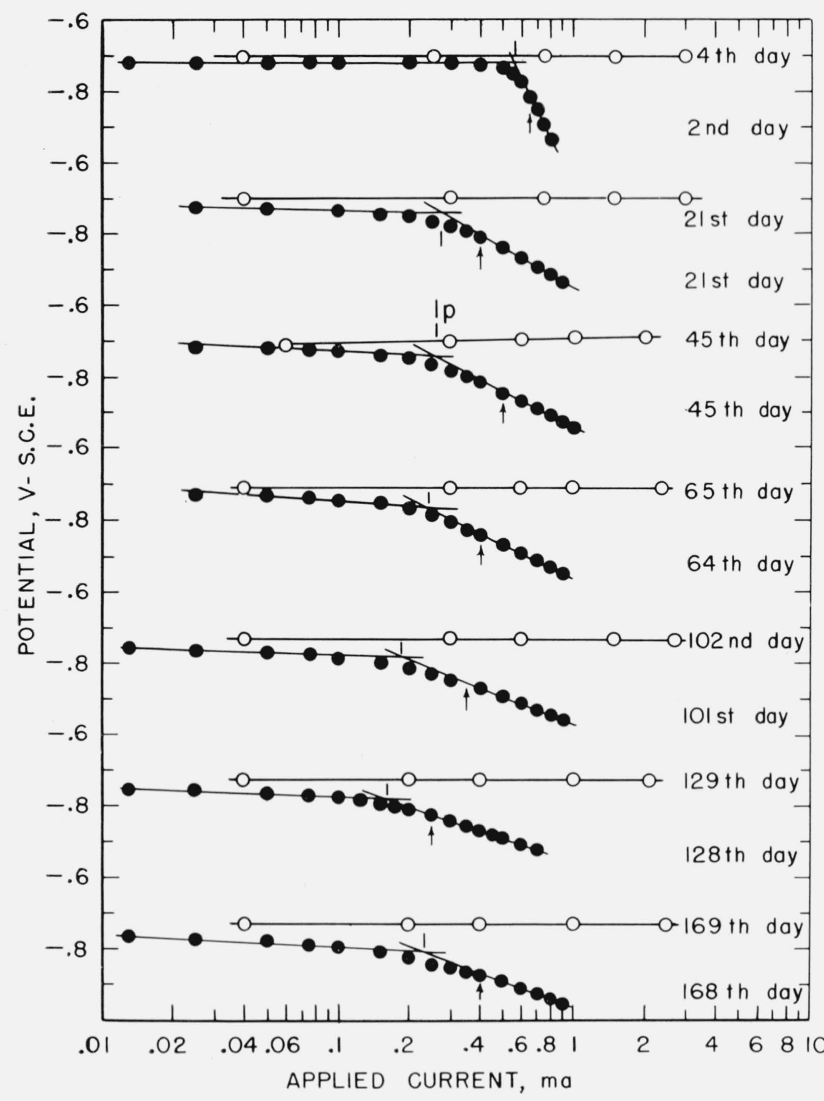

Figure 5. Some polarization curves of alloy control 9 during 6 months of exposure to salt solution in wooden vat.

0 -anodic, - - cathodic; Arrow shows probable beginning of hydrogen-overvoltage curve.

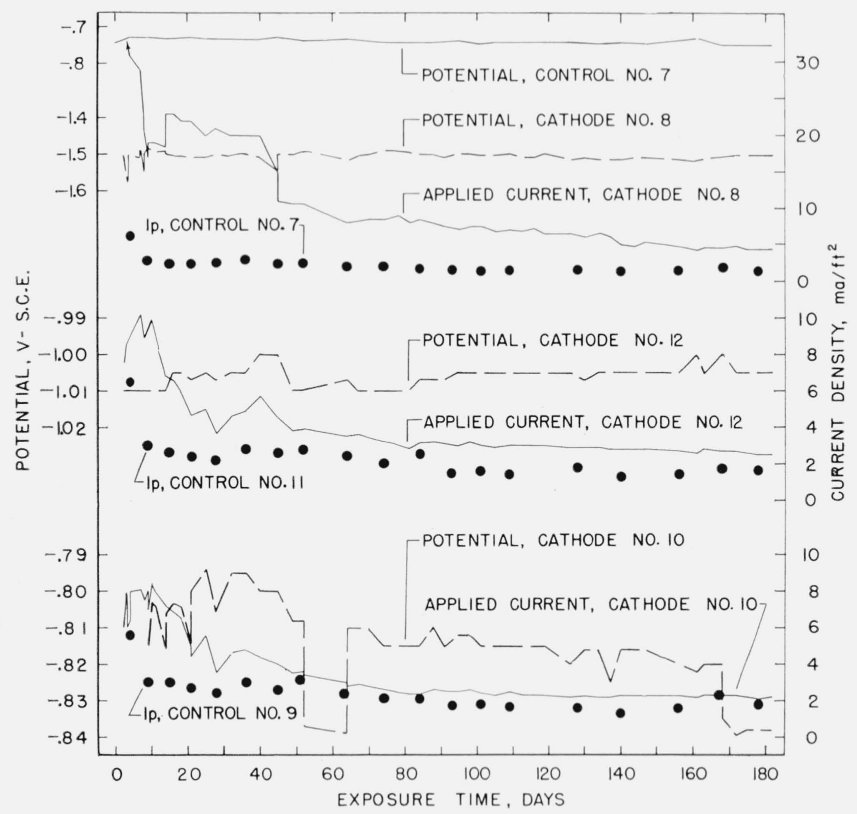

FIgure 6. Relation between applied currents ( $t 5$ cathodes) and currents $\left(I_{p}\right)$ indicated by cathodic polarization curves (of controls) for aluminum alloy in salt solution (wooden vat) Cathodes are controlled by three potential criteria, as shown.

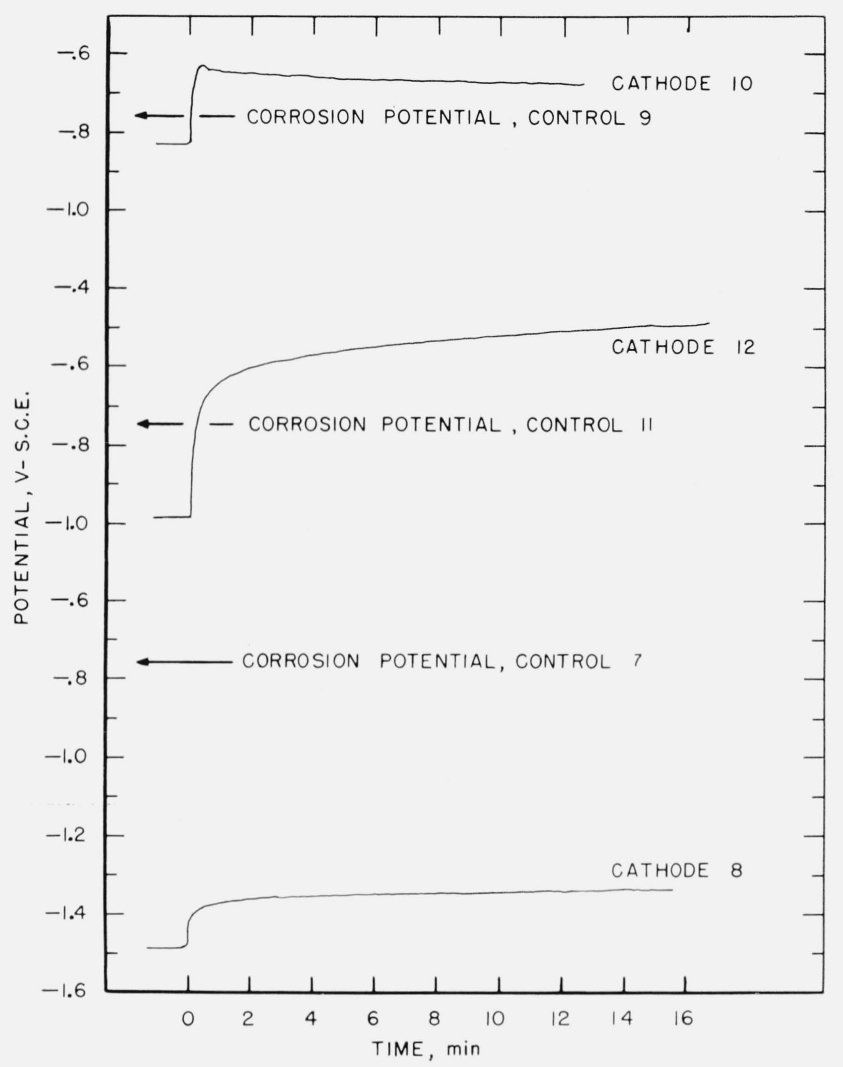

Figure 7. Potential-decay curves of cathodes exposed to salt solution of $p \mathrm{H} 8$ following removal of currents applied for 6 months.

Some preliminary results obtained with the same type and size of specimens are believed to be worthy of mentioning. A control, cathode and anode were exposed for 5 months to a salt solution in a setup similar to that just described, except that soil rings were omitted. During exposure, the control gradually become more anodic, changing in potential from $-0.73 \mathrm{~V}$ to $-1.107 \mathrm{~V}$. Based on cathodic polarization curves, obtained on the control periodically during exposure and indicating cathodic control, it was decided to hold the potential of the cathode about $0.1 \mathrm{~V}$ anodic to the potential of the control at all times. The $p \mathrm{H}$ of the salt solution gradually increased from 7.9 to 8.2 and the current density on the cathode decreased from $3.4 \mathrm{~mA} / \mathrm{ft}^{2}$ at the beginning to $0.05 \mathrm{~mA} / \mathrm{ft}^{2}$ at the end of exposure. The metal loss on the control due to corrosion was $147 \mathrm{mg}$, being mostly under the tape at the waterline and in pits over the exposed surface. The cathode lost $38 \mathrm{mg}$ yet there was little visual evidence of corrosion.

All of the polarization data obtained on the controls exposed to city water with 3 percent $\mathrm{NaCl}$ added are given in table 2 . These data are used to calculate corrosion rates for comparison with actual rates as revealed by the weight losses. It will be noted that the corrosion reactions of the specimens exposed to salt water in the wooden vat were under 
TABLE 2. Corrosion rates of alloy controls as calculated from polarization curves

Exposure for 6 months to salt solution $(p \mathrm{H} 8)$

\begin{tabular}{|c|c|c|c|c|c|c|c|c|c|c|c|}
\hline \multicolumn{6}{|c|}{ Specimen No. 7} & \multicolumn{6}{|c|}{ Specimen No. 9} \\
\hline \multirow{2}{*}{$\begin{array}{c}\text { Exposure } \\
\text { time }\end{array}$} & \multicolumn{2}{|c|}{$\begin{array}{l}\text { Current at break } \\
\text { in curve a }\end{array}$} & \multirow{2}{*}{$\begin{array}{c}\text { Corrosion } \\
\text { current } \\
i_{0} \mathrm{~b}\end{array}$} & \multicolumn{2}{|c|}{ Weight loss ${ }^{c}$} & \multirow{2}{*}{$\underset{\text { time }}{\text { Exposure }}$} & \multicolumn{2}{|c|}{$\begin{array}{l}\text { Current at break } \\
\text { in curve a }\end{array}$} & \multirow{2}{*}{$\underset{\substack{\text { Corrosion } \\
\text { current } \\
i_{\mathrm{o}} \mathrm{b}}}{ }$} & \multicolumn{2}{|c|}{ Weight loss ${ }^{c}$} \\
\hline & $\begin{array}{c}\text { Cathodic } \\
I_{p}\end{array}$ & $\begin{array}{c}\text { Anodic } \\
I_{q}\end{array}$ & & $\begin{array}{l}\text { Calculated } \\
\text { cumulative }\end{array}$ & Actual & & $\begin{array}{c}\text { Cathodic } \\
I_{p}\end{array}$ & $\underset{I_{q}}{\text { Anodic }}$ & & $\begin{array}{l}\text { Calculated } \\
\text { cumulative }\end{array}$ & Actual \\
\hline $\begin{array}{c}\text { Days } \\
4 \\
9 \\
15 \\
21 \\
28 \\
36 \\
45 \\
52 \\
64 \\
74 \\
84 \\
93 \\
101 \\
109 \\
128 \\
140 \\
156 \\
168 \\
178 \\
182\end{array}$ & $\begin{array}{l}m A \\
0.62 \\
.30 \\
.26 \\
.24 \\
.25 \\
.30 \\
.25 \\
.26 \\
.21 \\
.20 \\
.17 \\
.15 \\
.13 \\
.13 \\
.14 \\
.12 \\
.14 \\
.17 \\
.14\end{array}$ & $\begin{array}{l}m A \\
3>I_{p} \\
3>I_{p} \\
3>I_{p} \\
3>I_{p} \\
3>I_{p} \\
3>I_{p} \\
3>I_{p} \\
3>I_{p} \\
3>I_{p} \\
3>I_{p} \\
3>I_{p} \\
3>I_{p} \\
3>I_{p} \\
3>I_{p} \\
3>I_{p} \\
>>I_{p}\end{array}$ & $\begin{array}{l}m A \\
0.62 \\
.30 \\
.26 \\
.24 \\
.25 \\
.30 \\
.25 \\
.26 \\
.21 \\
.20 \\
.17 \\
.15 \\
.13 \\
.13 \\
.14 \\
.12 \\
.14 \\
.17 \\
.14\end{array}$ & $\begin{array}{r}m g \\
20 \\
38 \\
52 \\
64 \\
78 \\
96 \\
116 \\
131 \\
154 \\
170 \\
185 \\
197 \\
206 \\
214 \\
234 \\
247 \\
264 \\
278 \\
291 \\
\mathrm{~d} 296\end{array}$ & 531 & $\begin{array}{r}\text { Days } \\
4 \\
9 \\
15 \\
21 \\
28 \\
36 \\
45 \\
52 \\
64 \\
74 \\
84 \\
93 \\
101 \\
109 \\
128 \\
140 \\
156 \\
168 \\
178 \\
182\end{array}$ & $\begin{array}{l}m A \\
0.56 \\
.30 \\
.30 \\
.27 \\
.24 \\
.30 \\
.26 \\
.31 \\
.24 \\
.21 \\
.21 \\
.17 \\
.18 \\
.16 \\
.16 \\
.13 \\
.15 \\
.23 \\
.18\end{array}$ & 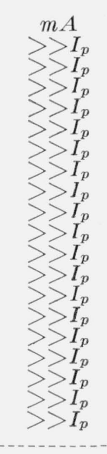 & $\begin{array}{l}m A \\
0.56 \\
.30 \\
.30 \\
.27 \\
.24 \\
.30 \\
.26 \\
.31 \\
.24 \\
.21 \\
.21 \\
.17 \\
.18 \\
.16 \\
.16 \\
.13 \\
.23 \\
.18\end{array}$ & $\begin{array}{r}m g \\
18 \\
35 \\
49 \\
63 \\
78 \\
95 \\
115 \\
131 \\
157 \\
176 \\
193 \\
207 \\
218 \\
229 \\
253 \\
268 \\
286 \\
304 \\
321 \\
\mathrm{~d} 327\end{array}$ & $\begin{array}{c}m g \\
\\
\end{array}$ \\
\hline \multicolumn{6}{|c|}{ Specimen No. 11} & \multicolumn{6}{|c|}{ Specimen No. 13} \\
\hline $\begin{array}{r}4 \\
9 \\
15 \\
21 \\
28 \\
36 \\
45 \\
52 \\
64 \\
74 \\
84 \\
93 \\
101 \\
109 \\
128 \\
140 \\
156 \\
168 \\
178 \\
182\end{array}$ & $\begin{array}{l}0.65 \\
.30 \\
.26 \\
.24 \\
.22 \\
.28 \\
.26 \\
.28 \\
.24 \\
.21 \\
.25 \\
.15 \\
.16 \\
.14 \\
.16 \\
.13 \\
.14 \\
.17 \\
.16\end{array}$ & 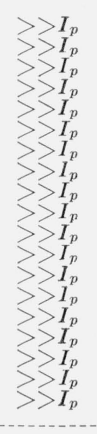 & $\begin{array}{l}0.65 \\
.30 \\
.26 \\
.24 \\
.22 \\
.28 \\
.26 \\
.28 \\
.24 \\
.21 \\
.25 \\
.15 \\
.16 \\
.14 \\
.16 \\
.13 \\
.14 \\
.17 \\
.16\end{array}$ & $\begin{array}{r}21 \\
40 \\
53 \\
65 \\
78 \\
94 \\
114 \\
129 \\
154 \\
172 \\
190 \\
204 \\
214 \\
224 \\
247 \\
261 \\
278 \\
293 \\
307 \\
\text { d } 312\end{array}$ & 543 & $\begin{array}{r}2 \\
8 \\
27 \\
33 \\
43 \\
53 \\
63 \\
75 \\
81 \\
91 \\
102 \\
118 \\
130 \\
147 \\
151 \\
158 \\
174 \\
180\end{array}$ & $\begin{array}{l}0.080 \\
.050 \\
.042 \\
.14 \\
.075 \\
.10 \\
.090 \\
.090 \\
.090 \\
.075 \\
.075 \\
.055 \\
.060 \\
.050 \\
.050 \\
.055\end{array}$ & $\begin{array}{c}e>I_{p} \\
>0 I_{p} \\
0.075 \\
\mathrm{e} .075 \\
\mathrm{e} .075 \\
.075 \\
.050 \\
.035 \\
.040 \\
.050 \\
.075 \\
.15 \\
\mathrm{e} .15 \\
.15 \\
\mathrm{e} .090 \\
.090\end{array}$ & $\begin{array}{c}0.080 \\
.050 \\
.027 \\
.049 \\
.038 \\
.043 \\
.032 \\
.025 \\
.026 \\
.031 \\
.032 \\
.043 \\
.037 \\
.032 \\
.034\end{array}$ & $\begin{array}{r}1.3 \\
4.4 \\
10.2 \\
12.0 \\
15.5 \\
18.8 \\
21.8 \\
25.9 \\
27.9 \\
30.4 \\
34.5 \\
38.1 \\
43.6 \\
46.7 \\
50.9 \\
52.5\end{array}$ & $\begin{array}{c}0 . \\
\end{array}$ \\
\hline
\end{tabular}

a See polarization curves - figures 5 and 8 for controls 9 and 13, respectively.

b $i_{0}=I_{p} I_{q} /\left(I_{p}+I_{q}\right) . \quad i_{\mathrm{o}}=I_{p}$ approximately, when $I_{q}>>I_{p}$.

- Calculated weight loss $(\mathrm{g})=k t i$, where $K=0.9316 \times 10^{-4} \mathrm{~g} / C, i=i_{0}=$ average current (amperes) for the period ( $t$ in seconds) between successive readings. The value of $i_{0}$ at the instant of exposure and at the end of exposure is taken as the initial and final values, respectively, as calculated. Weight loss in $\mathrm{mg}=$

$8.05 t i_{\circ}$, approximately; where $t=$ days, $i_{0}=\mathrm{mA}$.

d By taking for $I_{p}$ the value of current at the assumed beginning of the hydrogen-over voltage curve (straight line through points, see fig. 5), the calculated values for specimens 7,9 , and 11 become, respectively, $499 \mathrm{mg}, 545 \mathrm{mg}$, and $517 \mathrm{mg}$. See the text.

e Assumed (no curve) on the basis of measurements made before or after cathodic control while the corrosion reactions of the pair of specimens with soil rings exposed to salt water in the glass jar were of mixed control. For controls 7,9 , and 11 , the use of the current indicated by the arrow on the cathodic polarization curves (fig. 5) in place of the current $I_{p}$ in the equation for corrosion rate (footnote $\mathrm{b}$, table 2 ) results in better agreement between calculated and actual weight losses (footnote $\mathrm{d}$, table 2 ). This observation is also suggested in some unpublished data on aluminum previously obtained by the author and also on published data on aluminum exposed underground [14]. The theoretical aspects of the current indicated by the arrow as a value required for complete cathodic protection (for iron) have been previously discussed by the author and by others $[15,16,17]$.

\subsection{Aluminum Alloy in Salt Solution of $p \mathrm{H} 10$}

Data on the aluminum alloy in salt water made alkaline $(p \mathrm{H} 10)$ by the addition of sodium carbonate are shown in tables 3 and 4 and in figures 10 and 11 . The sodium carbonate has caused the corrosion to be under anodic control (fig. 10 and table 4) and apparently made cathodic protection impossible and undesirable because the cathodic currents produced cathodic corrosion (table 3 ) and greatly accelerated corrosion over that on the controls. Also, noteworthy is how an increase in polarization potential of the cathodes (from - 1.3 to - $1.5 \mathrm{~V}$ ) stepped up the corrosion rate tremendously.

The potential-decay curves (fig. 12) obtained on cathodes 16 and 18 at the end of exposure are indicative of cathodic corrosion. The greater corrosion on 


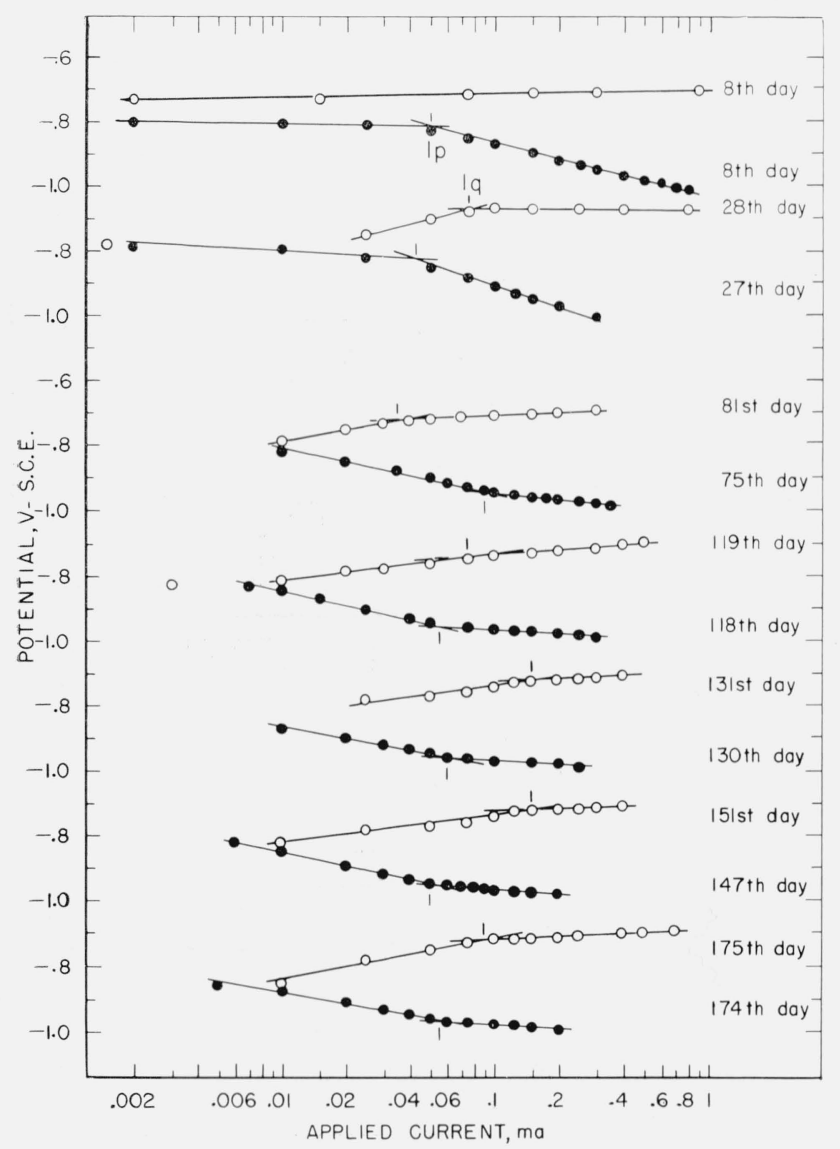

Figure 8. Some polarization curves of control 13 during 6 months of exposure to salt solution and soil in jar. 0 -anodic; --cathodic.

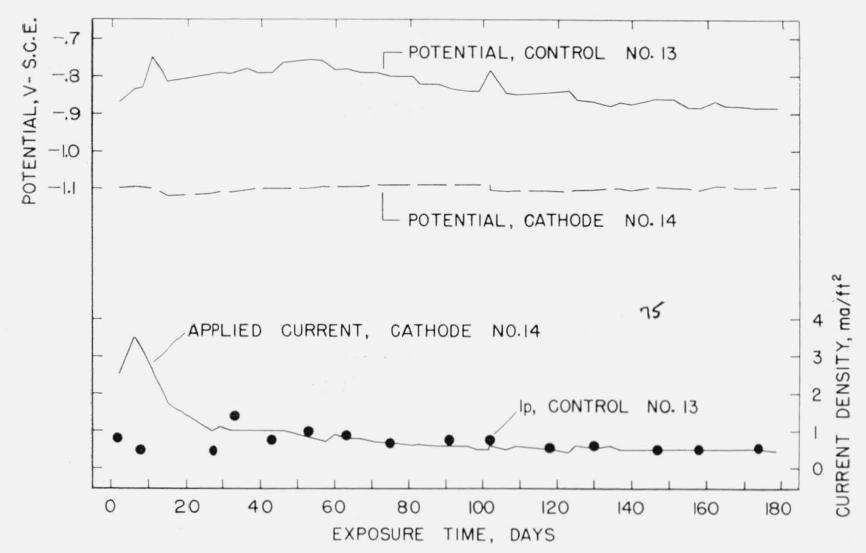

Figure 9. Relation between applied current (to cathode) and currents $\left(\mathbf{I}_{p}\right)$ indicated by cathodic polarization cr rves (of control) for aluminum alloy exposed to saltwater and soil in jar.

Cathode held at about -1.1 volt as shown

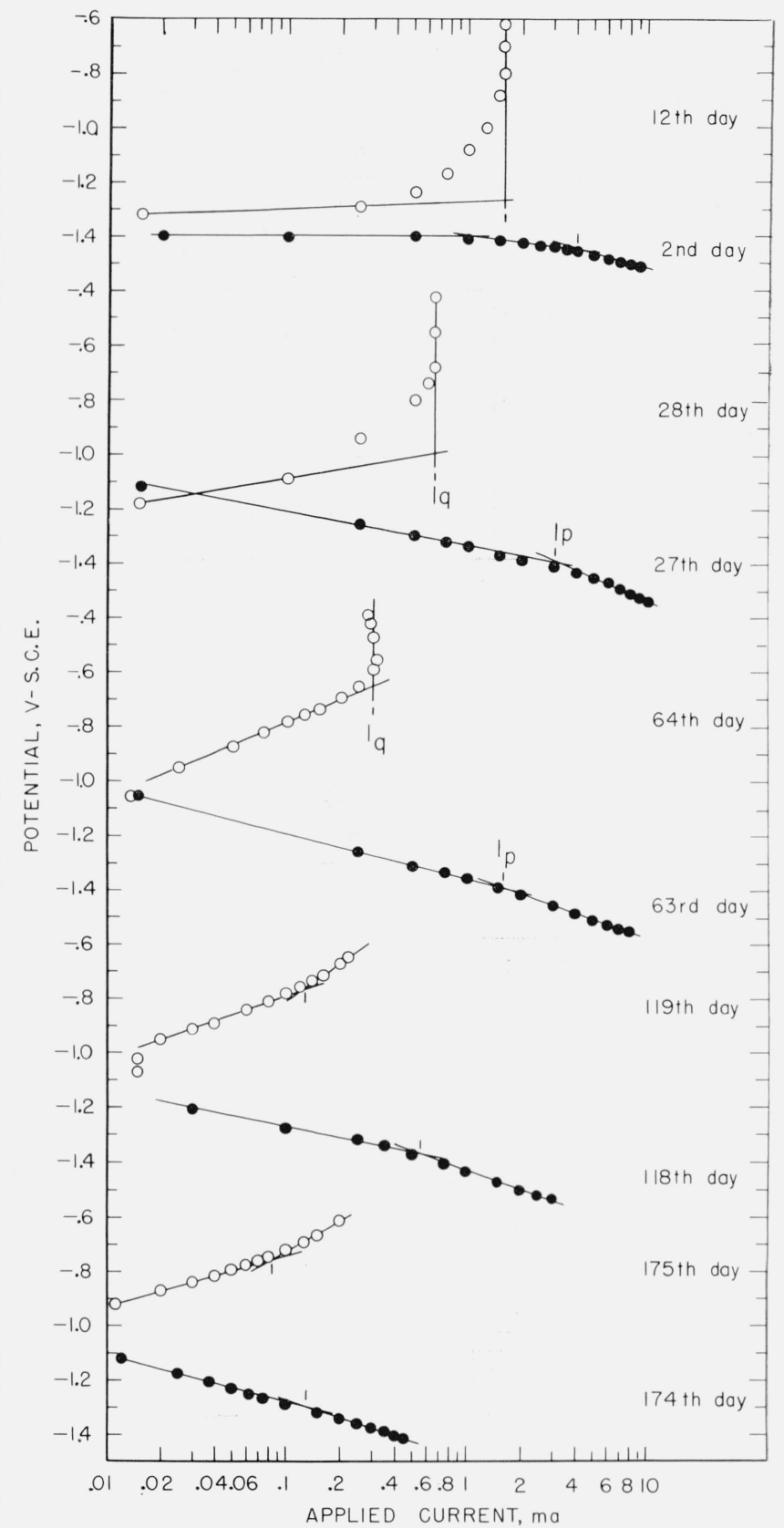

Figure 10. Some polarization curves of alloy control 15 during 6 months of exposure to salt solution of $p \mathrm{H} 10$.

0 -anodic; $\bullet-$ cathodic

cathode 18 is predictable from the curves. That the applied cathodic currents were not unnecessarily high is indicated by the fair agreement of the polarization currents, $I_{p}$, on the controls with the applied currents to the cathodes (fig. 11). An additional reason for believing that lower values of applied currents would not have resulted in cathodic protection lies in the fact that calculated corrosion rates (table 4) using the currents $I_{p}$ are in reasonable agreement with the actual corrosion rates. However, it should be noted that the corrosion current (table 4) 
TABLE 3. Effect of cathodic currents on aluminum alloy (6063-T5) exposed for 6 months to salt solution ( $p \mathrm{H} 10)$

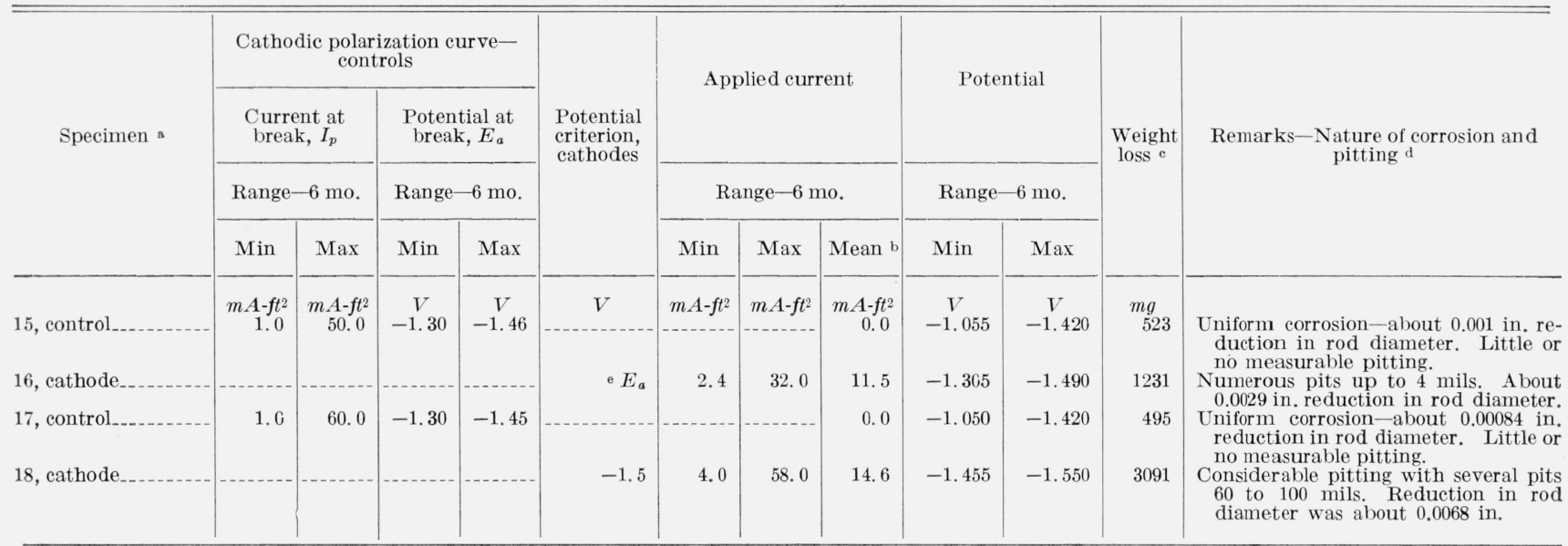

a Specimens 15 and 16 were exposed to 4.5 gal of solution contained in one glass jar and specimens 17 and 18 to the same kind of solution in a second jar.

b Based on area under current-time curve (fig. 11).

c Exposed area $0.1 \mathrm{ft}^{2}$.

d Rod diameter change based on average change of 25 measurements made with micrometer caliper on both exposed and unexposed parts of the specimen.

e $E_{a}$, Potential corresponding to $I_{p}$, cathodic polarization curve of control No. 15 .

TABLE 4. Corrosion rates of alloy controls as calculated from polarization curves

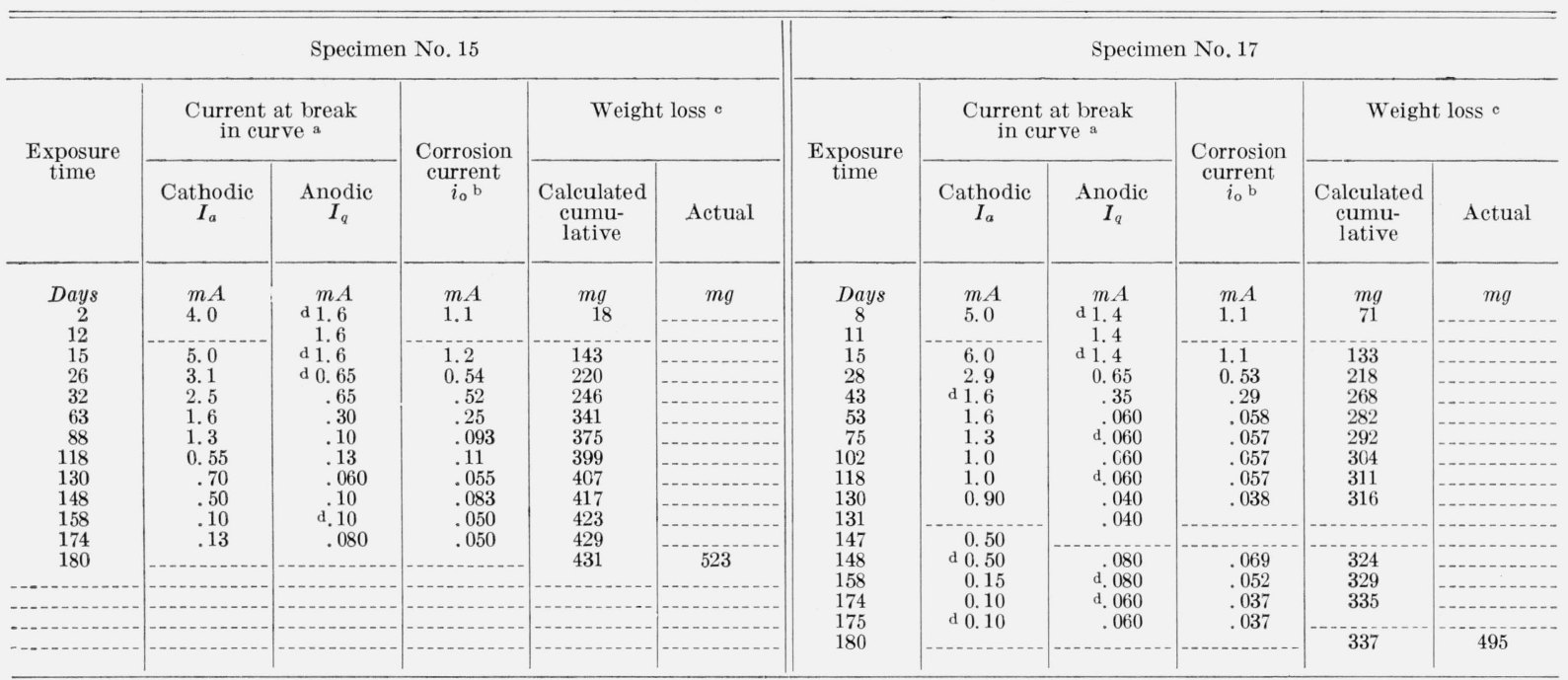

a See polarization curves-figure 10 .

b $i_{0}=I_{p} I_{q} /\left(I_{p}+I_{q}\right)$.

- Calculated weight loss $(\mathrm{g})=k t i$, where $K=0.9316 \times 10^{-4} \mathrm{~g} / \mathrm{C}, \quad i=i_{\mathrm{o}}=$ average current (amperes) for the period ( $t$ in seconds) between successive readings.
The value of $i_{\mathrm{o}}$ at the instant of exposure and at the end of exposure is taken as the initial and final values, respectively, as calculated. Weight loss in $\mathrm{mg}=$ $8.05 t i_{\mathrm{o}}$, approximately; where $t=$ days, $i_{\mathrm{o}}=\mathrm{mA}$.

d Assumed (no curve) on basis of measurements made before or after diminished greatly with time and that the corrosion reaction was becoming less under the influence of anodic control. This suggests the possibility that eventually, given additional time of exposure, cathodic protection might have been possible, for example on cathode 16 .

\subsection{Aluminum Alloy in Salt Solution of $p \mathrm{H} 4$}

Data on the aluminum alloy in salt water made acid $(p \mathrm{H} 4)$ by the addition of acetic acid are shown in tables 5 and 6 and in figures 13 and 14.
The data indicate that cathodic protection is necessary and possible in such an environment. Of the two potential criteria used, polarization to about $-1.0 \mathrm{~V}$ seems to be the more desirable. The potentials and the corrosion rates seemed to be very susceptible to changes in solution temperature and therefore the temperature (typical of all solutions in jars) of the acid solution is shown in figure 14 . The corrosion rate (corrosion current, table 6) is more stable over the long run than the rates for any of the other exposures and is under strict cathodic control (fig. 13). Thus, the current required for cathodic 
TABLE 5. Effect of cathodic currents on aluminum alloy (6063-T5) exposed for 6 months to salt solution ( $p H$ 4)

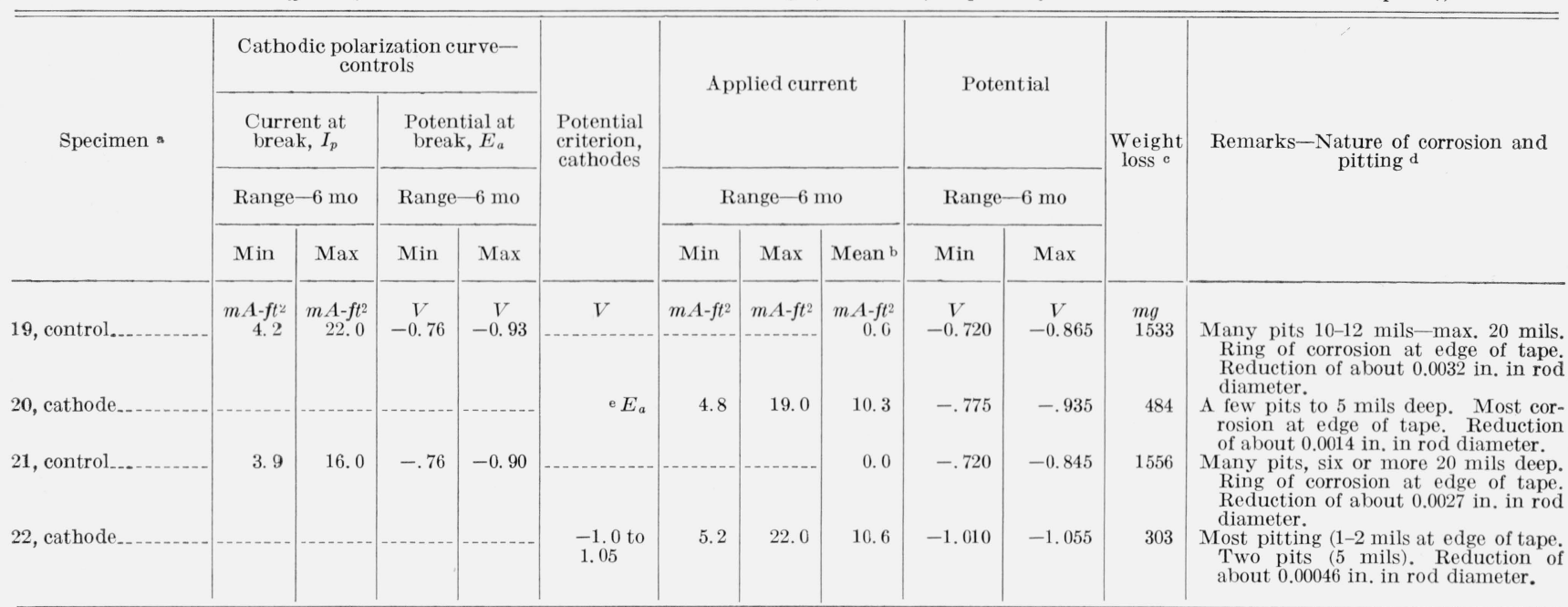

a Specimens 19 and 20 were exposed to 4.5 gal of solution contained in one glass jar and specimens 21 and 22 to the same solution in a second jar.

b Based on area under the current-time curve (fig. 14).

d Rod diameter change based on average change of 25 measurements made with micrometer caliper on both exposed and unexposed parts of the specimen.
e $E_{a}$, potential corresponding to $I_{p}$, cathodic polarization curve of control

- Exposed area $0.1 \mathrm{ft}^{2}$. No. 19 .

TABLE 6. Corrosion rates of alloy controls as calculated from polarization curves

Exposure for 6 months to salt solution $(p \mathrm{H} 4)$.

\begin{tabular}{|c|c|c|c|c|c|c|c|c|c|c|c|}
\hline \multicolumn{6}{|c|}{ Specimen No. 19} & \multicolumn{6}{|c|}{ Specimen No. 21} \\
\hline \multirow{2}{*}{$\begin{array}{c}\text { Exposure } \\
\text { time }\end{array}$} & \multicolumn{2}{|c|}{$\begin{array}{l}\text { Current at break } \\
\text { in curve a }\end{array}$} & \multirow{2}{*}{$\begin{array}{c}\text { Corrosion } \\
\text { current } \\
i_{0} \text { b }\end{array}$} & \multicolumn{2}{|c|}{ Weight loss ${ }^{c}$} & \multirow{2}{*}{$\begin{array}{c}\text { Exposure } \\
\text { time }\end{array}$} & \multicolumn{2}{|c|}{$\begin{array}{l}\text { Current at break } \\
\text { in curve }{ }^{\mathrm{s}}\end{array}$} & \multirow{2}{*}{$\begin{array}{c}\text { Corrosion } \\
\text { current } \\
i_{0} \mathrm{~b}\end{array}$} & \multicolumn{2}{|c|}{ Weight loss ${ }^{\mathrm{c}}$} \\
\hline & $\begin{array}{l}\text { Cathodic } \\
I_{p}\end{array}$ & $\underset{I_{q}}{\text { Anodic }}$ & & $\begin{array}{l}\text { Calculated } \\
\text { cumulative }\end{array}$ & Actual & & $\begin{array}{l}\text { Cathodic } \\
I_{p}\end{array}$ & $\underset{I_{q}}{\text { Anodic }}$ & & $\begin{array}{l}\text { Calculated } \\
\text { cumulative }\end{array}$ & Actual \\
\hline $\begin{array}{c}\text { Days } \\
2 \\
15 \\
27 \\
33 \\
43 \\
63 \\
71 \\
75 \\
90 \\
119 \\
130 \\
147 \\
158 \\
173 \\
180\end{array}$ & $\begin{array}{l}m A \\
1.6 \\
1.6 \\
2.2 \\
1.3 \\
0.75 \\
.64 \\
.54 \\
.56 \\
.75 \\
1.4 \\
0.60 \\
1.4 \\
0.42 \\
1.0 \\
-\end{array}$ & 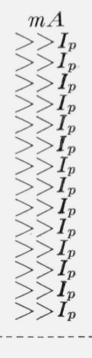 & $\begin{array}{l}m A \\
1.6 \\
1.6 \\
2.2 \\
1.3 \\
0.75 \\
.64 \\
.54 \\
.56 \\
.75 \\
1.4 \\
0.60 \\
1.4 \\
0.42 \\
1.0\end{array}$ & $\begin{array}{r}m g \\
26 \\
193 \\
376 \\
464 \\
544 \\
657 \\
695 \\
713 \\
791 \\
1047 \\
1135 \\
1272 \\
1352 \\
1438 \\
1494\end{array}$ & $\begin{array}{c}m g \\
\end{array}$ & $\begin{array}{r}\text { Days } \\
8 \\
54 \\
81 \\
102 \\
119 \\
130 \\
147 \\
158 \\
173 \\
180 \\
\end{array}$ & $\begin{array}{l}m A \\
1.5 \\
1.0 \\
0.85 \\
.75 \\
1.6 \\
0.85 \\
1.1 \\
0.39 \\
.75\end{array}$ & 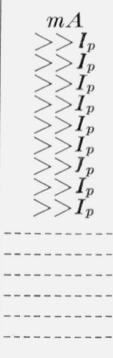 & $\begin{array}{l}m A \\
1.5 \\
1.0 \\
0.85 \\
.75 \\
1.6 \\
0.85 \\
1.1 \\
0.39 \\
.75 \\
\end{array}$ & $\begin{array}{r}m g \\
97 \\
578 \\
778 \\
913 \\
1077 \\
1183 \\
1316 \\
1382 \\
1451 \\
1493 \\
\end{array}$ & 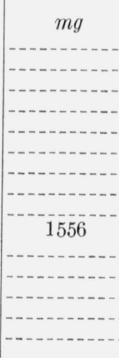 \\
\hline
\end{tabular}

a See polarization curves-figure 13 .

b $i_{0}=I_{p} I_{q} /\left(I_{p}+I_{q}\right)$. $i_{0}=I_{p}$ approximately, when $I_{q}>>I_{p}$.

b $i_{0}=I_{p} I_{q} /\left(I_{p}+I_{q}\right) \cdot i_{0}=I_{p}$ approximately, when $I_{q}>>I_{p}$.
c Calculated weight loss $(\mathrm{g})=k t i$, where $\mathrm{K}=0.9316 \times 10^{-4} \mathrm{~g} / C, \quad i=i_{0}=$ average ${ }^{\circ}$ Calculated weight loss $(\mathrm{g})=k t i$, where $\mathrm{K}=0.9316 \times 10^{-4} \mathrm{~g} / C, i=i_{0}=$ average
current (amperes) for the period ( $t$ in seconds) between successive readings. The

protection is equal to the corrosion current as verified by the good agreement between calculated and actual weight losses (table 6).

Observations of decay potentials (fig. 15) when applied currents were removed from the cathodes after 6 months of exposure are again of interest and as previously reasoned are indicative of cathodic protection. Greater depolarization took place on cathode 22 which had the better degree of protection. The relation between the cathode potential after depolarization and the control corrosion potential is probably value of $i_{0}$ at the instant of exposure and at the end of exposure is taken as the initial and final values, respectively, as calculated. Weight loss in $\mathrm{mg}=8.05 t i_{0}$, approximately; where $t=$ days, $i_{0}=\mathrm{m} A$. 


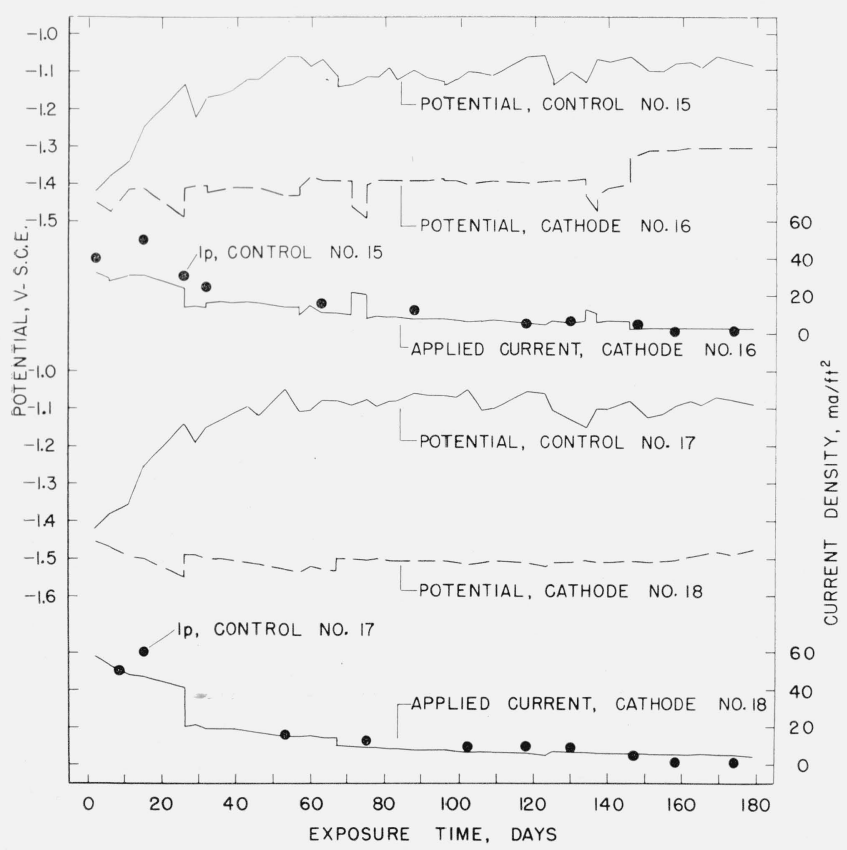

FiguRE 11. Relation between applied currents (to cathodes) and currents $\left(\mathrm{I}_{p}\right)$ indicated by cathodic polarization curves (of controls) for aluminum alloy exposed to salt solution of $p \mathrm{H} 10$.

Cathodes are controlled by two potential criteria, as shown.

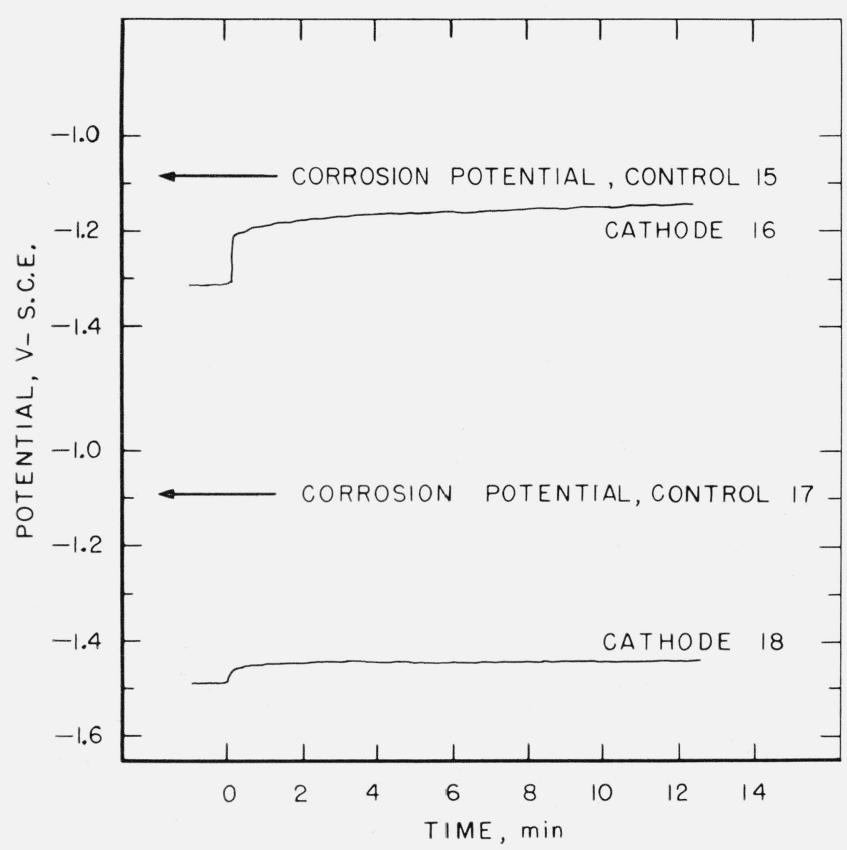

Figure 12. Potential-decay curves of cathodes exposed to salt solution of ${ }_{p} \mathrm{H} 10$ following removal of currents applied for 6 months.

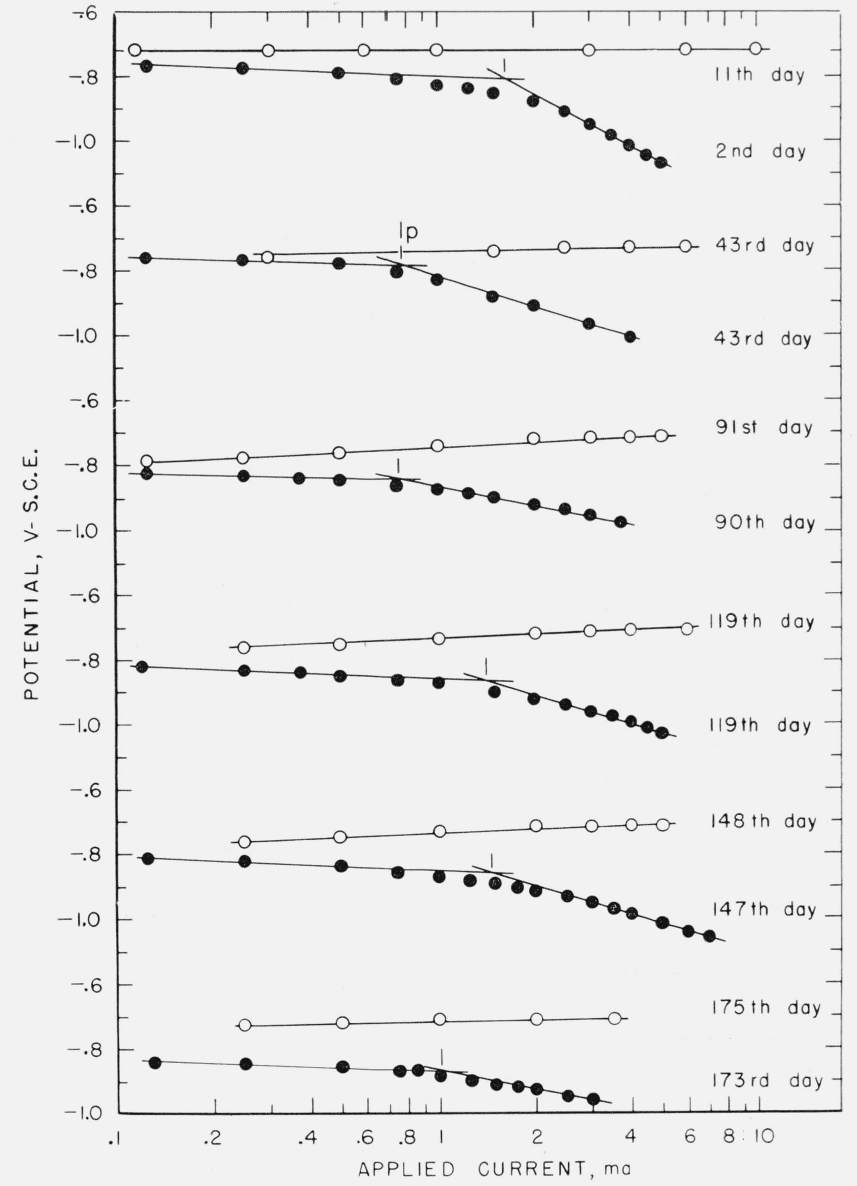

Figure 13. Some polarization curves of alloy control 19 during 6 months of exposure to salt solution of $p \mathrm{H} 4$. 0 -anodic; $\bullet$-cathodic.

$1500 \mathrm{ohm}-\mathrm{cm}$. After stabilization, the potentials of the specimens in 20 of the 21 soils were between -0.68 and $-0.98 \mathrm{~V}$ (S.C.E.) and the potential in the remaining soil $(p \mathrm{H} 10)$ was $-1.36 \mathrm{~V}$. Except for the latter soil, there seemed to be no particular relation between potential and $p H$. The corrosion which occurred during the 6 months was only superficial in nature. In order to observe the effect of aeration of the soils on the potentials of the alloy and on the corrosion rates, that is, under more normal conditions of exposure,one specimen of each pair was observed for an additional 18 weeks by making air accessible. The result was that all potentials became more cathodic and, except for 2 soils with fairly high resistivities, the corrosion rates increased tremendously with pits up to 110 mils deep. The selection of a protective potential generally applicable to aluminum alloys underground is considered undesirable because of the danger of cathodic corrosion.

Aluminum alloy (6063-T5) specimens were exposed to still city water with 3 percent sodium chloride added contained in a large open wooden vat $(265$ gal) and also to water similarly treated contained by 4.5 gal Pyrex jars. Of five jars, the $p H$ (8) of the water in one jar was left unchanged while the water 


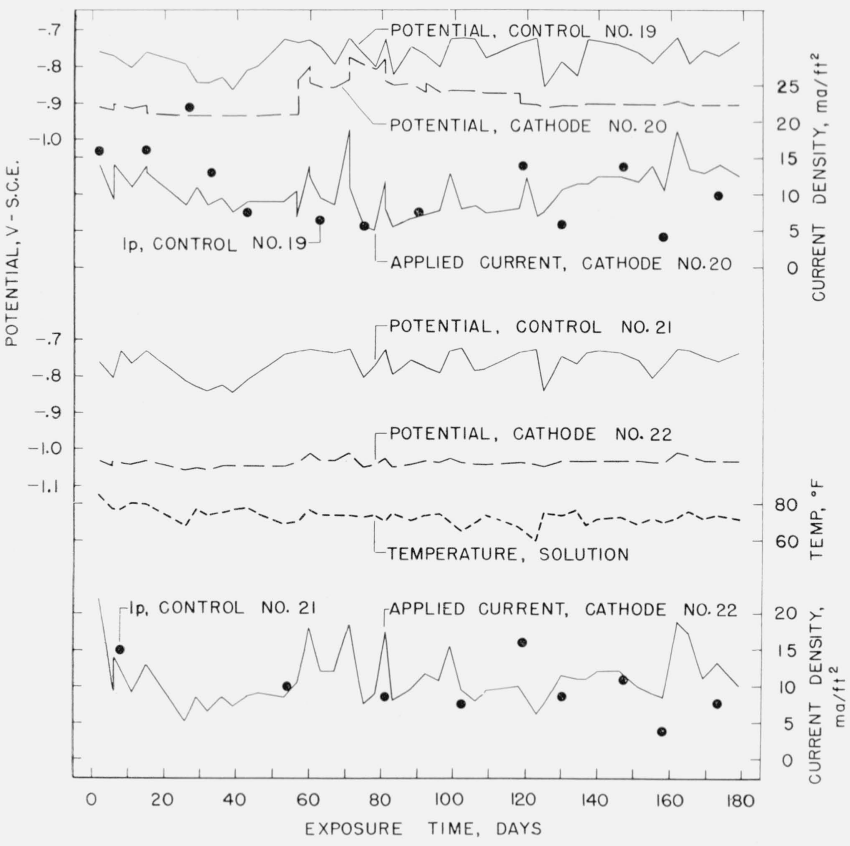

FIgURE 14. Relation between applied currents (to cathodes) and currents $\left(\mathrm{I}_{p}\right)$ indicated by cathodic polarization curves (of controls) for aluminum alloy exposed to salt solution of $p \mathrm{H} 4$.

Cathodes are controlled by two potential criteria, as shown.

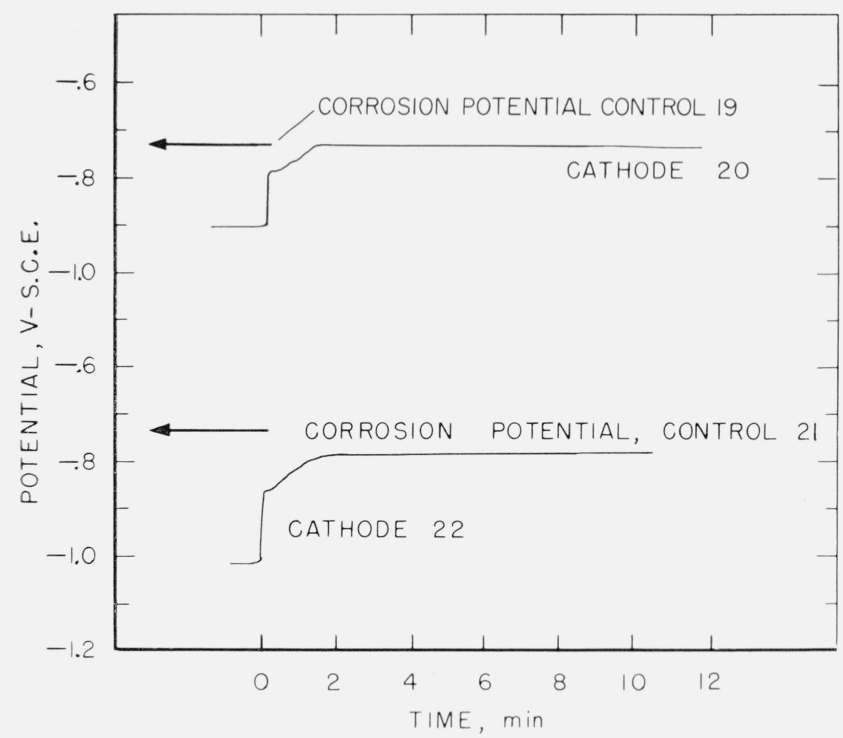

Figure 15. Potential-decay curves of cathodes exposed to salt solution of $p \mathrm{H} 4$ following removal of currents applied for 6 months. in two jars was adjusted to $p \mathrm{H} 4$ by the addition of acetic acid and the water in the other two jars was adjusted to $p \mathrm{H} 10$ by the addition of sodium carbonate. All specimens were exposed for 6 months.

Six specimens were exposed to the salt solution in the wooden vat, 3 being left to corrode freely and the other 3 with cathodic currents applied after corroding freely for 2 days. The currents were dependent on controlled potentials, namely, a value from the cathodic polarization curve, potential of a high purity zinc anode (about $-1 \mathrm{~V}$ ), and the potential of $-1.5 \mathrm{~V}$ (S.C.E). The $-1.5 \mathrm{~V}$ potential caused severe cathodic corrosion while the other two potentials provided about equal degrees of cathodic protection, the more anodic potential of the zinc being somewhat better in reducing pitting under the tape at the waterline.

Measurements were made on a pair of specimens in the jar of salt water, a control and a cathode, each fitted with a rubber cap containing clay soil in contact with about 12 percent of the area exposed. A ring of corrosion which had occurred adjacent to the rubber on the control was hardly perceptible on the cathode which was held at about $-1.1 \mathrm{~V}$, yet corrosion was not arrested.

A pair of specimens consisting of a control and a cathode were exposed in each of the 2 jars containing the acidic-salt water. In one of the jars the cathode was controlled by the potentials $(-0.775$ to -0.935 $\mathrm{V}$ ) periodically obtained from the cathodic polarization curves of the control while the cathode in the other jar was held between -1.01 and $-1.05 \mathrm{~V}$. Cathodic protection was achieved on both and was better on the cathode held in the more anodic range of potentials. The current density necessary for protection was well indicated by the current at the breaks in the cathodic polarization curves of the controls.

Cathodic corrosion took place on the two cathodes which were exposed to the salt solution of $p \mathrm{H} 10$.

Potential-decay curves obtained on all cathodes when applied currents were removed after 6 months of continuous exposure gave a clue as to whether the accumulative cathodic effects were protective or corrosive in nature.

Thanks are due Ray I. Lindberg, Metallurgical Research Laboratories, Reynolds Metals Company, who furnished the aluminum anodes used in some of the experiments. The cooperation of Melvin Romanoff, Corrosion Section, National Bureau of Standards, in permitting the use of one of his test sites and some of his unpublished data is appreciated.

\section{References}

[1] R. B. Mears and R. H. Brown, Industrial Engineering Chemistry 29, 1087 (1937).

[2] B. P. Caldwell and V. J. Albano, Rate of solution of zinc and aluminum white cathodic, Trans. E.C.S. $\boldsymbol{\gamma} 6,271$ (1939). 
[3] R. B. Mears and R. H. Brown, ibid, p. 283.

[4] R. B. Mears, Trans. A.I.C.E. 3\%, No. 6 (Dec. 25, 1941.)

[5] Edward T. Wanderer and Donald O. Sprowls, Aluminum alloys for offshore pipelines, Corrosion 8, 227 (July 1952).

[6] R. S. Dalrymple, Underground aluminum gas line, Corrosion 12, 602t (Dec. 1956).

[7] E. Deltombe and M. Pourbaix, The electrochemical behavior of aluminum; potential- $p H$ diagram of the System $\mathrm{Al} \cdot \mathrm{H}_{2} \mathrm{O}$ at $25{ }^{\circ} \mathrm{C}$, Corrosion 14, 496t (Nov. 1958).

[8] D. O. Sprowls and M. E. Carlisle, Jr., Resistance of aluminum alloys to underground corrosion, Corrosion 17, 125 (Mar. 1961).

[9] J. F. Whiting and T. E. Wright, Cathodic protection for an uncoated aluminum pipeline, Corrosion 17, 9 (Aug. 1961)

[10] F. W. Hewes, Investigation of maximum and minimum criteria for the cathodic protection of aluminum in soil, paper presented at the 18th Annual Conference, National Association of Corrosion Engineers, Kansas City, Missouri, March 1962.

[11] Melvin Romanoff, Underground corrosion, NBS Circ. 579 .
[12] David J. G. Ives and George J. Janz, Reference Electrodes, (Academic Press, New York and London, 1961).

[13] W. J. Schwerdtfeger and O. N. McDorman, Measurement of the corrosion rate of a metal from its polarizing characteristics, J. Electrochem. Soc. 99, 407 (1952).

[14] W. J. Schwerdtfeger: A study by polarization techniques of the corrosion rates of aluminum and steel underground for sixteen months, J. Res. NBS 65C (Engr. and Instr.) No. 4, 271 (Oct.-Dec. 1961).

[15] W. J. Schwerdtfeger and O. N. McDorman, Potential and current requirements for the cathodic protection of steel in soils, J. Res. NBS 47, 104 (1951) RP2233; Corrosion 8, 391 (1952).

[16] Scott Ewing, Proc. Am. Gas Assoc. 613 (1940).

[17] E. W. Haycock, Current requirements for cathodic protection of oil well casings, Corrosion 13, 767t (Nov. 1957).

(Paper 68C4-175) 